Article

\title{
The Impact of Eco-Label on the Young Chinese Generation: The Mediation Role of Environmental Awareness and Product Attributes in Green Purchase
}

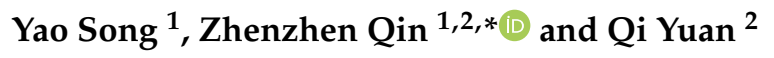 \\ 1 School of Design, The Hong Kong Polytechnic University, Hongkong 999077, China; \\ yao.song@connect.polyu.hk \\ 2 School of Journalism and Communication, Anhui Normal University, Anhui 241002, China; \\ qiyuanahsd@foxmail.com \\ * Correspondence: zhen.qin@connect.polyu.hk; Tel.: +852-6063-0402
}

Received: 30 December 2018; Accepted: 23 January 2019; Published: 14 February 2019

\begin{abstract}
Environmental surroundings are highly shaped by consumer choice. Eco-label has been discussed as an effective tool for promoting such environmental product information from the producer to the consumer in relevant literature; however, the young generation has seldom been examined in previous research. Additionally, studies on the structural process of eco-label's impact on green purchase remain limited, especially the mediation effects within the process. Regarding this research gap, the current study empirically tested the effects of eco-label on product attributes, environmental attitude, environmental concern and consequent purchase behavior from the young Chinese generation perspective. The intermediary role of product attribute is first investigated in the labeling-driven purchase, and the environmental attitude and concern are tested respectively to better understand the young generation's awareness, compared to previous relevant studies. Based on the appropriate sample collection ( $\mathrm{N}=699)$, a structural equation model (SEM) was used, and results statistically showed the impact of eco-label mediated by product attributes on environmental attitude and environmental concern, and how green purchase behavior was influenced through this process significantly. Theoretical contributions and managerial implications are also discussed in this study.
\end{abstract}

Keywords: Eco-label; green purchase; environmental attitude; environmental concern; product attributes; young Chinese generation

\section{Introduction}

Environmental surroundings are profoundly shaped by consumer choice [1-3]. China, with dense population and rapid economic growth in the last decades, is facing its own unique ecological challenges [4]. As shown in the previous studies, Chinese consumers are even less aware of the environmental issues, compared with other regions [5]. Recently, the young generation, as the potential largest consumption group, has increasingly gained attention in order to promote an environmentally friendly purchase. Statistically, it implies promising marketing of green consumption [6,7].

In this context, implementation of eco-information programs calls for effective communication with consumers directly [2]. Among these programs, eco-information labels and declarations (referred to further in this paper as eco-labels or eco-labeling) have been discussed in the relevant literature as a useful tool for promoting such environmental product information from the producer to the consumer [8]. Many researchers have attempted to understand its interlink with consumer behavior; some studies investigate how consumers make an informed choice after exposure to eco-labeled products [9-11], while others focus on the determinants of paying attention to eco-labels [12-14]. 
The substantial effects on green consumption revealed in recent research are controversial and even more complex than expected [15].

Additionally, environmental awareness improved by eco-label shows controversial results when utilizing the scales of environmental attitude and concern respectively $[16,17]$. The mixture of environmental attitude and concern tends to influence the effects of eco-labeling in consumers' psychological reactions. A clear distinction between these two concepts will be beneficial to give a clearer picture of the relationship between eco-labeling and consumption behavior.

More recent literature reveals a potential connection between eco-labeling and the corresponding product attribute. Some scholars state that a sufficient understanding of the critical attributes associated with organic production may inform consumers' purchase behavior $[16,18]$. Green product developments addressing environmental problems have exerted more efforts on designing recognizable characteristics of related products for consumers [19]. In this context, eco-label tends to be an essential factor of green products to influence consumers' purchase decisions [20]. However, whether there is a strong relationship between eco-label and the perceived product attribute is still open to investigation.

Demographic diversity is also verified in identifying the information of eco-labeling; the young age group shows a relatively higher level of satisfaction towards such labels than older and middle age group [21]. However, there are also concerns about the young generation's material consumption [22]. These controversial observations about the young generation's purchasing behavior call for further in-depth investigation. As the most powerful consumer group, the young generation can contribute more considerably to generate better implications for current sustainable business [23].

To address the questions as mentioned above, we employ an empirical study to verify the impact of eco-labeling on young Chinese peoples' perceptions towards environmental attitude and concern respectively through the intermediary product attribute, and how green purchase is ultimately informed. The relations examined in this research can offer a more comprehensive understanding of the current eco-label and green consumption with the consideration of demographic diversity. With regard to the practical perspective, the results can contribute to the marketing and design strategies in the field of environmentally friendly product development to benefit environmental sustainability. From social perspectives, young generations' awareness towards a green future could be enhanced to a certain extent by this empirical study. Figure 1 shows a flow diagram of the present study.

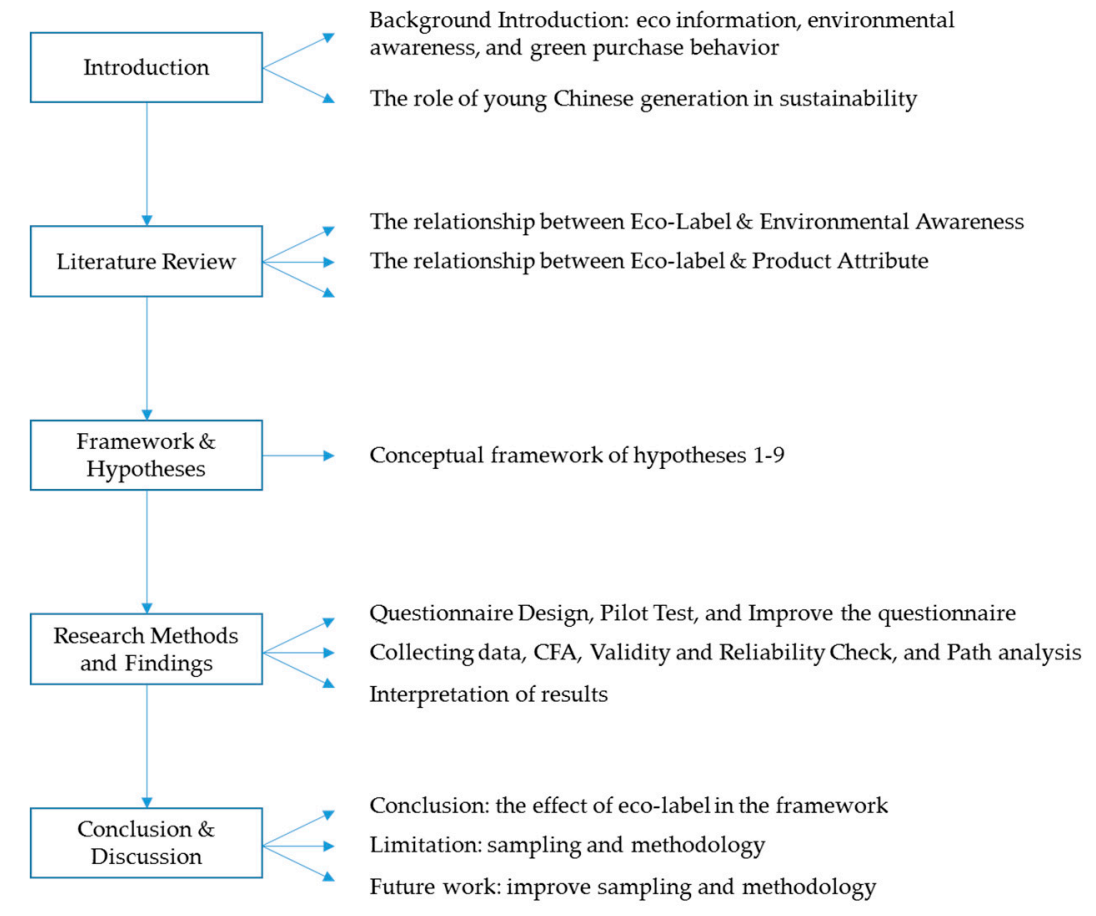

Figure 1. The structure of the current study. 


\section{Literature Review}

In this section, we present a theoretical background of the present research. Firstly, we discuss the definition and concept of eco-label and its theoretical impact on green consumption in the context of sustainable development, and how environmental awareness acts as an intermediary factor. Secondly, the perceived product attribute influenced by eco-label is introduced to propose the possible relationship between eco-label and environmental awareness. Finally, from a marketing perspective, we argue that environmental attitude and green purchase are interlinked with each other through the mediator of environmental concerns.

\subsection{Eco-Label and Environmental Awareness}

Over recent decades, eco-labeling has worked as a strategic tool to communicate the environmental-friendly concerns of products [24,25]. Its positive impact has been realized by firms and organizations in promoting the identity of green products, and advertising green consumptions [1]. In 2002, Massachusetts Department of Environmental Protection released a report, which stated that consumers are facing confusion in locating and recognizing green products [26]. In this context, eco-labeling has been defined as any recognizable symbol attached to the product or its packaging, indicating a company, or a product's performance orientated by the environmental friendliness $[27,28]$. Recent studies construe that consumers' purchase behavior tends to be guided by eco-labels shown on products [11,12], as it may assist consumers to identify the environmentally friendly product and make the least environmentally damaging purchase decision. In this way, such market failures caused by information asymmetry have the potential to be reduced [29,30]. For example, Tang et al. [13] verify that eco-label design with both visual and verbal communications is relatively effective in informing consumers' purchase behavior. Nilsson et al. [31] suggest that eco-labels situated in the immediate surroundings of products in shops are a crucial information source for consumers to learn about environmental concerns.

Though the theoretical relationship between eco-labeling and green purchase has been investigated before [15], the in-depth understanding of its structural process is seldom studied empirically, especially the mediation effects within the process. More recent literature reveals the significant determinant of environmental awareness, which improves consumers' psychological perceptions towards green purchases [32]. For example, Thøgersen [12] verifies that consumers' perpetual priority regarding environmental sustainability tends to determine their resulting actions. The perceived relevance between business and environmental surroundings plays an essential role in the consumer decision-making process [33]. However, the process of how eco-label informs environmental awareness and encourages sustainable consumption is seldom examined.

Present studies addressing environmental awareness are strongly connected with attitudinal awareness. Fishbein and Ajzen [34] conclude that environmental awareness and sensitivity may be influenced by attitudes. Within the new environmental paradigm (NEP), the environmental attitude has been traditionally viewed as and measured by a unidimensional construct ranging from unconcerned about the environment at the low end to concerned at the high end [35,36]. However, the relationship between environmental attitude and peoples' resulting behaviors have been discussed recently; studies reveal that sometimes the association is weak [37-43]. This controversial evidence tends to suggest that environmental attitude is not sufficient for environmental actions to be implemented.

Additionally, more recent research shows that environmental concern is often discussed and studied in relation to the measurement of environmental awareness. Many relevant studies utilized the scales of environmental concern to measure the general awareness of environmental issues, which are centered on people's motivation for environmentally friendly behaviors [44]. It can be anticipated that people have related themselves to the environmental issues though being concerned about the environment $[42,45,46]$. As such, it is promising to investigate how eco-labels possibly affect the purchase behaviors by considering both environmental attitude and environmental concern as mediators in this process. 
The young generation, as a potentially large group of participants in pro-environmental activities and a large group for product consumption, has been emphasized in environmental protection and related pro-environmental activities, and this phenomenon is examined on environmental issues statistically [22]. Studies show they tend to incline towards sustainable behaviors much more, compared with older generations [6]. Nevertheless, prior studies undertake limited consideration of the role of the young generation from the eco-label perspective.

Therefore, based on the above theoretical observations, we present the following hypothesis aiming at better understanding the effects of eco-label on consumers' environmental awareness:

H1. The eco-label has a positive impact on environmental attitude.

H2. The eco-label has a positive impact on environmental concern.

H3. The eco-label has a positive impact on green purchase behavior.

\subsection{Eco-Label as A Product Attribute}

Previous studies show that the ethical attributes of products may motivate consumers' attitudinal behavior, and tend to be an effective determinant for translating positive attitudes into actual purchasing actions [47-49]. For instance, some scholars have verified that the appearance of the word "green" appears to have a significant effect on people's purchase intention [50,51]. In this context, the eco-label is regarded as one of the most recognizable attributes of green products to inform consumers' purchase decisions [20], improving transparency and confidence concerning environmental and social assertions [52]. Empirical studies propose that the awareness of integrating environmental concerns into product attributes is prevalent in companies' product development [53]. Eco-labels tends to be a crucial factor to influence consumers' purchase decision when a green product is relatively expensive or lower quality [1]. In other words, the product attribute of eco-labeling plays a dominant role compared with other conventional attributes, such as functional qualities.

However, some studies reveal that eco-labels are not sufficient to indicate the recognizable information about green products [1]. Several studies reported that consumers' green purchase intention and behavior are influenced by other quality-driven factors significantly, rather eco-labeling $[47,54,55]$. For instance, perceived functional quality of green products influences consumers' decision-making $[47,48,54,55]$. It has been proposed that consumers with a preference for environmental and social responsibilities look for environmentally friendly attributes, whereas consumers that attach higher importance to individual consequences seek functional attributes in a product. Health considerations are strong predictors of green consumption [56].

Simon [57] suggests the products labeled by environmental friendliness conform to new attitudes toward environmental values. An awareness regarding environmental concerns is considered a pre-condition for consumers to pay attention to the relevant product attributes [12]. The relevant provision of information may influence consumers' perceptual value upon an environmentally friendly commodity [58,59]. Meanwhile, some scholars pay attention to the informative functions of eco-labeling as an educative medium. Tang et al. [13] propose that products attached to the eco-labels themselves offer a communicative approach to offer costumers' the relevant information regarding environmental concerns. Relevant research measures the effectiveness of eco-labeling on influencing consumers' environmental awareness after exposure to label information [60].

With regard to these controversial observations, the necessity of examining the interaction between eco-labeling and environmental awareness draws on the distinctive role of product attributes of green consumptions as an intermediary variable. If eco-labeling tends to be an influential factor to enhance the consumers' perceptions of product attitudes, it is anticipated that eco-labeling and relevant information make a distinctive contribution to shape the perceivable attribute of environmentally friendly product.

Consequently, we formulate the following hypotheses based on the above discussion: 
H4. The eco-label has a positive impact on product attributes.

H5. The product attributes have a positive impact on environmental attitude.

H6. The product attributes have a positive impact on environmental concern.

\subsection{Environmental Awareness and Green Purchase}

With the long history of sustainable research, an individual's awareness for the environment is fundamental and crucial [37]. It denotes an individual's general attitude towards the environment and an individual's concern level as to environmental issues and has been verified to be a sufficient determinant of environmentally conscious actions ranging from recycling behavior $[61,62]$ to green purchasing behavior $[1,63,64]$. The study shows that consumers with stronger environmental awareness are more likely to purchase products as a result of their environmental claims and social responsibility [65].

As discussed in Section 2.1, an individual's environmental concern has also been found more close to the consequential purchase behavior, compared to the attitudinal awareness. Some scholars argue that environmental concern refers to an individual's fundamental beliefs or values of environmental ethics [36,66]. Schultz and Zelezny [67] suggest that environmental concerns are positively influenced by altruistic values including biospherism, but are negatively related to egoistic values such as collectivism. On the other hand, some studies investigate the relationships between collectivism, environmental concerns, and green purchase behaviors is a hierarchical model of value-attitude-behavior [68]. In this way, the potential consequence between attitudinal awareness and environmental concerns is anticipated.

However, the effectiveness of the psychological determinants of environmentally friendly behavior is controversial. The relevant behavioral research reports a positive relationship between knowledge and behavior $[69,70]$, while some studies have shown that ecological knowledge exerts no prominent bearing on eco-friendly behaviors [71]. Such findings suggest a more complex connection between ecological knowledge and behavior [4]. In this context, the mediatory role of conscious awareness of environmental issues is proposed to better build the relationship of environmental attitudes and consequent behaviors [69]. Therefore, this study first argues the intermediary factor of environmental concern is the potential to connect the environmental attitude and green purchase under the impact of eco-labeled product attribute.

H7. The environmental attitude has a positive impact on environmental concern.

H8. The environmental attitude has a positive impact on green purchase behavior.

H9. The environmental concern has a positive impact on green purchase behavior.

\section{Research Framework and Hypotheses}

Based on our review of prior related research, we assume that the eco-label plays a significant role in product attribute evaluation, environmental awareness, and consequent purchase intention. In this section, we empirically test the research framework that shows the impacts of eco-label from the perspective of the young Chinese generation. This research framework is intended to help us have insights into the relationship between different variables; and the effects of eco-labels and the perception of related environmental awareness on consumers' behavior reactions.

Figure 2 presents the research framework and hypotheses developed following the above reasoning. As shown in Figure 2, there are nine hypotheses formulated to answer the research questions stated above. 


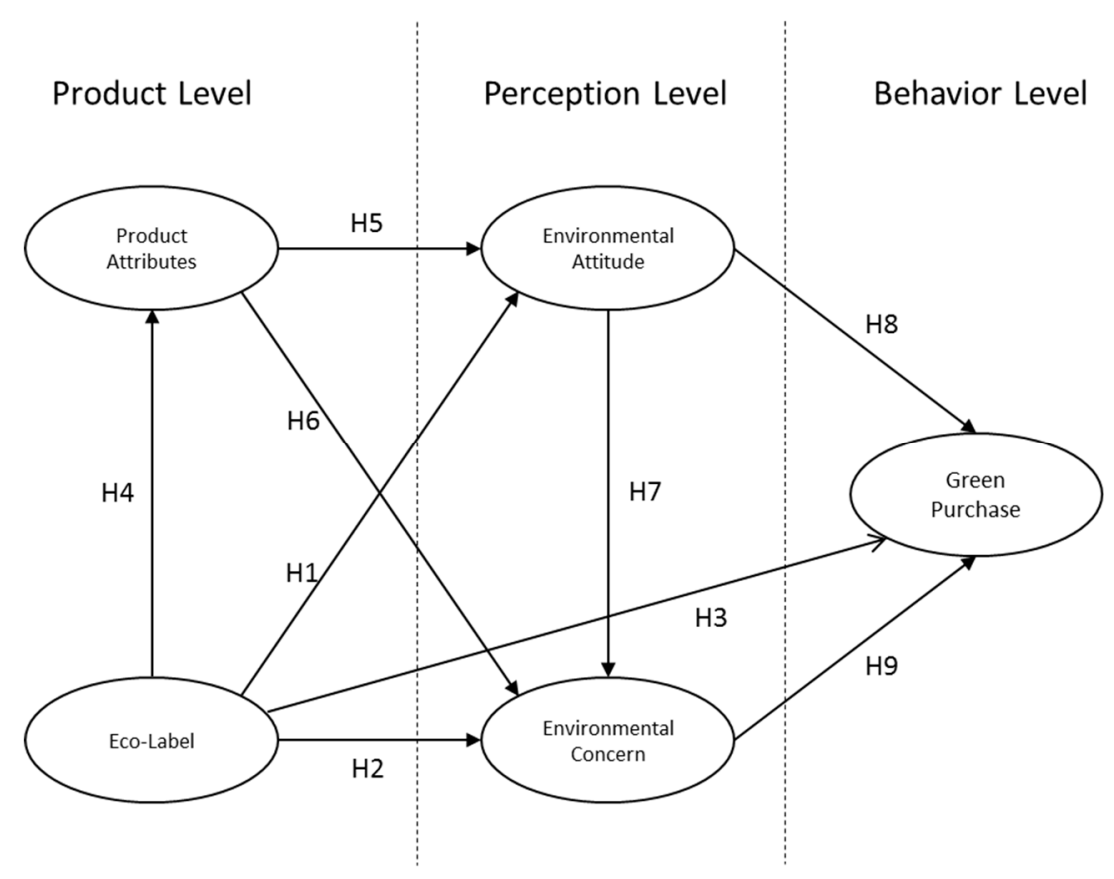

Figure 2. The conceptual framework of hypotheses.

\section{Research Methods}

In order to validate our research framework, an empirical study was employed by collecting survey responses from major universities in Beijing and Anhui which are allocated in the northern and eastern part of China, respectively. Beijing is the capital of China; therefore Beijing participants stand for the young northern Chinese generation who are more associated with traditional culture [72]. On the other hand, Anhui is one of the major provinces in the eastern part of China. Therefore participants stand for the young eastern Chinese generation, believed to be more sensitive to new concepts and ideas [73]. As the broad distribution of young Chinese generation, the current sampling tries to control the influence from different localizations, to some extent, to represent a general picture of Chinese young people.

\subsection{Measures}

Table 1 shows the measurements that have been used to validate Research Hypotheses 1-9. To specify, there are five measurements associated with the current study and each measurement item or scale was all adapted from the previous relevant studies (Table 1). The detail could be found in Appendix A. In this way, we developed a survey which contained the related measurement items and demographic questions. 
Table 1. Measures for the Research Model.

\begin{tabular}{|c|c|c|c|}
\hline Measure & Definition & Measure Items & Reference \\
\hline Product Attributes & $\begin{array}{l}\text { a characteristic that defines a particular } \\
\text { product and will affect a consumer's } \\
\text { purchase decision. }\end{array}$ & $\begin{array}{l}\text { Eco-friendly designed product looks appealing. } \\
\text { Eco-friendly designed product looks stylish. } \\
\text { Eco-friendly product is of good quality. }\end{array}$ & $\begin{array}{l}\text { Praxmarer, } 2011 \text { and } \\
\text { Chen et al., } 2015\end{array}$ \\
\hline Eco-Label & $\begin{array}{l}\text { a voluntary method of environmental } \\
\text { performance certification and labelling } \\
\text { that is practiced around the world. }\end{array}$ & $\begin{array}{l}\text { If possible, I would like to buy products with recycling label } \\
\text { Marketers must advertise the environmental aspects of } \\
\text { their products. } \\
\text { Government must make eco-labeling mandatory. }\end{array}$ & Nittala, 2014 \\
\hline Environmental Attitudes & $\begin{array}{l}\text { a psychological tendency expressed by } \\
\text { evaluating the natural environment with } \\
\text { some degree of favour or disfavour. }\end{array}$ & $\begin{array}{l}\text { When humans interfere with nature it often produces disastrous } \\
\text { consequences. } \\
\text { The balance of nature is very delicate and easily upset. } \\
\text { We are approaching the limit of the number of people the Earth } \\
\text { can support. }\end{array}$ & Kim, 2011 \\
\hline Environmental Concern & $\begin{array}{l}\text { a consumer's beliefs about society's role in } \\
\text { considering and protecting the } \\
\text { environmentally concerned behavior. }\end{array}$ & $\begin{array}{l}\text { I try to buy energy-efficient household appliances. } \\
\text { I try to buy products that can be recycled. } \\
\text { To save energy, I drive my vehicle as little as possible. }\end{array}$ & Straughan and Roberts, 1999 \\
\hline Green Purchase & $\begin{array}{l}\text { a procurement of products and services } \\
\text { that have a lesser or reduced effect on } \\
\text { human health and the environment when } \\
\text { compared with competing products or } \\
\text { services that serve the same purpose. }\end{array}$ & $\begin{array}{l}\text { I make a special effort to buy paper and plastic products that are } \\
\text { made from recycled materials. } \\
\text { I have switched products for ecological reasons. } \\
\text { When I have a choice between two equal products, I purchase the } \\
\text { one less harmful to other people and the environment. } \\
\text { I make a special effort to buy household chemicals such as } \\
\text { detergents and cleansing solutions that are } \\
\text { environmentally friendly. } \\
\text { I have avoided buying a product because it had potentially } \\
\text { harmful environmental effects. }\end{array}$ & Kim and Choi. 2005 \\
\hline
\end{tabular}




\subsection{Survey Procedure and Response Rate}

Firstly, we ran a pilot study checking whether the survey was appropriately designed to fulfill the research objectives stated above. 27 university students enrolled in the pilot study. By revising and reorganizing the redundant questions, we confirmed the consistency of this survey, making this survey as clear and concise as possible.

In order to get a better understanding of environmental perception and the resultant behavioral reaction within the research framework from the young Chinese generation perspective, a total number of 2349 questionnaires were sent randomly and individually from the instructors to university students through Wechat and QQ. The list of university students was collected from academic secretaries of related Beijing and Anhui universities for students of various regions. A total of 699 unique and usable responses were received (response rate of $29.7 \%$ ).

\section{Findings}

SPSS 22 for Windows and AMOS 24 for Windows were used to perform the related statistical analysis, analyzing the relationship among different variables. To specify, the SPSS software was mainly used to check the reliability of scales and measurement items and summarize the demographical information, while the AMOS software was introduced to perform the confirmatory factor analysis (CFA) of different constructs, and run the structural equation model (SEM) to figure the model fit and related path analysis.

The demographic information of the study is summarized in Table 2. The largest age group in this study was 18 years old, accounting for $37.91 \%$ of all the participants. The next largest age group was the age 19 and age 20, accounting for $33.33 \%$ and $19.60 \%$ of all the participants respectively. Other demographical information was also summarized in Table 2.

Table 2. Demographic Information of the Participants.

\begin{tabular}{|c|c|c|c|}
\hline Attributes & Value & Frequency & Percentage (\%) \\
\hline \multirow[t]{2}{*}{ Gender } & Male & 108 & $15.45 \%$ \\
\hline & Female & 591 & $84.55 \%$ \\
\hline \multirow[t]{5}{*}{ Age } & $16-17$ & 26 & $3.72 \%$ \\
\hline & 18 & 265 & $37.91 \%$ \\
\hline & 19 & 233 & $33.33 \%$ \\
\hline & 20 & 137 & $19.60 \%$ \\
\hline & $21-34$ & 38 & $5.44 \%$ \\
\hline \multirow[t]{3}{*}{ Education } & High school & 4 & $0.57 \%$ \\
\hline & Undergraduate & 690 & $91.27 \%$ \\
\hline & Postgraduate & 5 & $0.72 \%$ \\
\hline \multirow[t]{3}{*}{ Region } & Anhui & 554 & $79.26 \%$ \\
\hline & Beijing & 123 & $17.60 \%$ \\
\hline & Other & 22 & $3.15 \%$ \\
\hline
\end{tabular}

\subsection{Reliability and Validity}

Reliability refers to the extent that a measurement item or scale produces similar responses under consistent conditions with consistent participants. To specify, Cronbach's alphas would work as an indicator to analyze the internal consistency of measurement items or scales of the survey. Table 3 summarizes the result of Cronbach's alphas in the current survey. All Cronbach's alphas and composite reliability (C.R.) of the measurement items and scales in the column were above 0.70 [74], suggesting all the constructs of this survey are statistically reliable.

Construct validity refers to the extent to which the correspondence between a measurement of the claimed construct and its operationalization. Notably, it contains four specific assessments: unidimensionality, convergent validity, discriminant validity, and nomological validity [74]. 
Unidimensionality refers to the extent to which a measurement item or scale has only one dimension. Regarding the unidimensionality of this study, we adopted confirmatory factor analysis (CFA) to check whether the measurement of a construct is corresponding to our comprehension of the nature of the construct (or factor). In particular, CFA was performed for all the five constructs to confirm that 18 indicators have measured the construct they were designed to adequately. Maximum likelihood (ML) estimation was used to evaluate our research framework statistically, and the criteria contained the Comparative Fit Index (CFI), the Root Mean Square Residual (RMSR), Goodness-of-Fit Index (GFI), Adjusted Goodness-of-Fit Index (AGFI), and so forth. Table 3 summarizes the reliability and unidimensionality of all five constructs.

Table 3. Reliability and Unidimensionality.

\begin{tabular}{|c|c|c|c|c|c|c|c|}
\hline Construct & $\begin{array}{c}\text { Cronback's } \\
\text { Alpha }\end{array}$ & Variable & $\begin{array}{l}\text { Standardized } \\
\text { Factor Loading }\end{array}$ & $\begin{array}{c}\text { C.R. } \\
\text { (t-Value) }\end{array}$ & SMC & AVE & $\begin{array}{l}\text { Composite } \\
\text { Reliability }\end{array}$ \\
\hline \multirow{3}{*}{$\begin{array}{c}\text { Environmental } \\
\text { Attitude }\end{array}$} & \multirow{3}{*}{0.800} & Atti1 & 0.730 & - & 0.533 & \multirow{3}{*}{0.579} & \multirow{3}{*}{0.805} \\
\hline & & Atti2 & 0.816 & 18.429 & 0.666 & & \\
\hline & & Atti3 & 0.734 & 17.235 & 0.539 & & \\
\hline \multirow{4}{*}{$\begin{array}{l}\text { Environmental } \\
\text { Concern }\end{array}$} & \multirow{3}{*}{0.850} & Con1 & 0.888 & - & 0.789 & \multirow{3}{*}{0.684} & \multirow{3}{*}{0.865} \\
\hline & & Con2 & 0.895 & 31.268 & 0.801 & & \\
\hline & & Con 3 & 0.681 & 20.647 & 0.464 & & \\
\hline & \multirow{3}{*}{0.736} & Label1 & 0.652 & - & 0.425 & \multirow{3}{*}{0.490} & \multirow{3}{*}{0.742} \\
\hline \multirow[t]{2}{*}{ Eco-label } & & Label2 & 0.729 & 14.713 & 0.531 & & \\
\hline & & Label3 & 0.716 & 14.558 & 0.513 & & \\
\hline \multirow{3}{*}{$\begin{array}{c}\text { Product } \\
\text { Attributes }\end{array}$} & \multirow{3}{*}{0.863} & Attri1 & 0.888 & - & 0.789 & \multirow{3}{*}{0.693} & \multirow{3}{*}{0.870} \\
\hline & & Attri2 & 0.890 & 27.804 & 0.792 & & \\
\hline & & Attri3 & 0.707 & 21.220 & 0.500 & & \\
\hline \multirow{5}{*}{$\begin{array}{c}\text { Green } \\
\text { Purchase }\end{array}$} & \multirow{5}{*}{0.903} & Gp1 & 0.790 & - & 0.624 & \multirow{5}{*}{0.653} & \multirow{5}{*}{0.904} \\
\hline & & Gp2 & 0.821 & 23.870 & 0.674 & & \\
\hline & & Gp3 & 0.852 & 25.027 & 0.726 & & \\
\hline & & Gp4 & 0.806 & 23.327 & 0.650 & & \\
\hline & & Gp5 & 0.769 & 21.974 & 0.591 & & \\
\hline
\end{tabular}

Note: C.R. (t-value) stands for $\mathrm{t}$-value; SMC stands for Square multiple correlation; AVE stands for averaged variances expected.

Convergent validity refers to the extent to which measures of every construct that are not only theoretically related to each other but, in fact, are observed to be related to each other. According to Fornell and Larcker [75] and Huang et al. [76], standardized factor loadings value should be 0.5 or above, and averaged variances expected (AVE) value should be 0.5 or above. In the current study, the results showed the minimum value of C.R. in our study $(=14.552)$ was much higher than the ' 2 ' threshold; minimum standardized factor loading $(=0.681)$ exceeded the ' 0.5 ' threshold. However, the lowest AVE calculated $(=0.490)$ is not above 0.50. According to Fornell and Larcker [75], we could accept 0.40 as the threshold for AVE since all the composite reliabilities are above 0.60; as a result, the convergent validity of the constructs is still adequate.

Discriminant validity refers to the situation in which scales, concepts or measurement items that are not supposed to be related are unrelated. We calculated the correlation coefficients of our research framework. Table 4 shows the maximum shared variance (MSV) and average shared variance (ASV) to assess discriminant validity (threshold: MSV < AVE and ASV < AVE) [75]. Results show AVE values are all above MSV and ASV values, ensuring that the five dimensions of the current research framework achieved adequate discriminant validity. 
Table 4. Correlation Matrix of the Constructs.

\begin{tabular}{cccccccccc}
\hline Construct & CR & AVE & MSV & ASV & EC & EL & PA & EA & GP \\
\hline Environmental Concern (EC) & 0.866 & 0.687 & 0.616 & 0.380 & 0.829 & & & & \\
Eco-label (EL) & 0.742 & 0.490 & 0.486 & 0.367 & $0.697^{* * *}$ & 0.700 & & & \\
Product Attributes (PA) & 0.870 & 0.693 & 0.263 & 0.219 & $0.393^{* * *}$ & $0.477^{* * *}$ & 0.833 & & \\
Environmental Attitude (EA) & 0.807 & 0.582 & 0.355 & 0.292 & $0.512^{* * *}$ & $0.538^{* * *}$ & $0.513^{* * *}$ & 0.763 & \\
Green Purchase (GP) & 0.904 & 0.653 & 0.616 & 0.417 & $0.785^{* * *}$ & $0.682^{* * *}$ & $0.482^{* * *}$ & $0.59^{* * *}$ & 0.808 \\
\hline
\end{tabular}

Note: $p<0.1 ;{ }^{* *} p<0.05 ;{ }^{* * *} p<0.01$; MSV stands for the maximum shared variance; ASV stands for average shared variance.

Nomological validity refers to a comparison of at least two constructs and that those constructs have a possible linkage. Considering the coefficient between environmental concern and green purchase, 0.785 , was relatively high, we performed a multi-collinearity test. Variance inflation factors (VIF) were introduced to evaluate the nomological validity (the threshold should be 10 or less). Results of VIF in our research framework suggested that VIFs ranged from 1.328 to 3.194, ruling out the potential threat of multicollinearity in this research; namely, nomological validity of this research framework is acceptable.

Moreover, we also checked the goodness-of-fit with absolute fit indices and incremental fit indices in our current framework. Table 5 shows the summarization of all the fit indices. To specify, SRMR (standardized root mean square residual), GFI and AGFI (goodness-of-fit index), RMSEA (root mean square error of approximation), NFI (normed fit index), IFI (incremental fit index), TLI (Tucker-Lewis index), and CFI (comparative fit index) were all within the respective thresholds. Therefore, the research framework was considered to be fitted to the responses collected.

Table 5. Goodness-of-Fit Test.

\begin{tabular}{llll}
\hline Category & Measure & Acceptable Values & Value \\
\hline Absolute fit indices & Chi-square & & 368.609 \\
& d.f. & & 110 \\
& Chi-square/d.f. & $1-5$ & 3.351 \\
& GFI & 0.90 or above & 0.942 \\
& AGFI & 0.90 or above & 0.919 \\
& SRMR & 0.08 or below & 0.028 \\
& RMSEA & $0.05-0.08$ & 0.059 \\
Incremental fit indices & NFI & 0.90 or above & 0.948 \\
& IFI & 0.90 or above & 0.963 \\
& TLI & 0.90 or above & 0.954 \\
& CFI & 0.90 or above & 0.962 \\
\hline
\end{tabular}

\subsection{Path Analysis}

The chief aim of this study is to understand the effect of eco-labels on the perception of environmental awareness, thus influencing consumer behavior. In order to analyze the relationship in the research framework, we conducted a path analysis based on a Structural Equation Model (SEM). Figure 3 shows the output of this analysis and Table 6 shows the standardized coefficient of each path and the results of the hypotheses. 


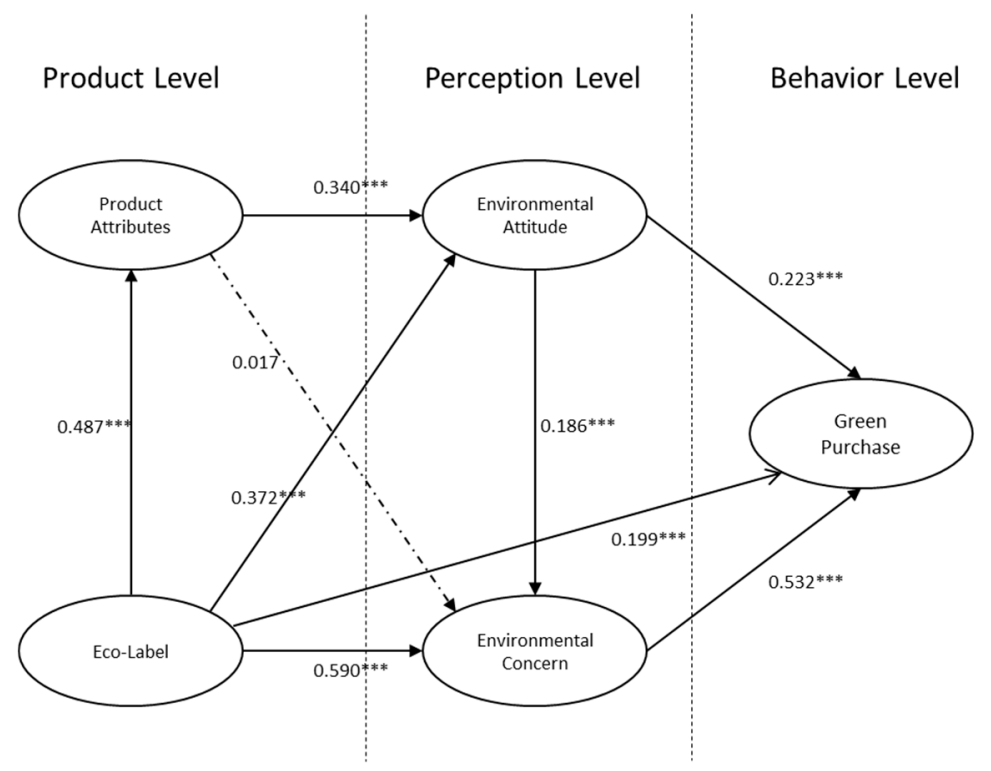

Figure 3. Path Coefficients Resulting from Structural Equation Modeling (SEM). Note: ${ }^{*} p<0.1$; ** $p<0.05 ;{ }^{* * *} p<0.01$.

Table 6. Hypothesis Testing.

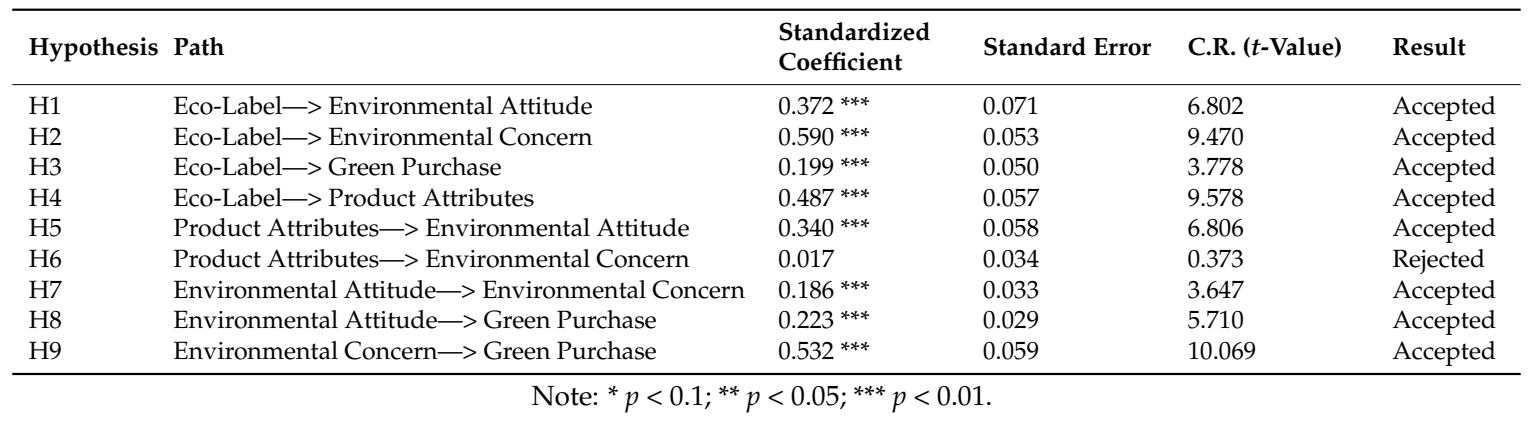

\section{Results and Discussion}

Results show that eight of the nine hypotheses were supported. First of all, eco-labels influence consumers' environmental attitude and concern significantly, with the coefficients of 0.372 and 0.590 respectively, verifying $\mathrm{H} 1$ and $\mathrm{H} 2$. This result suggested that eco-labels play an important role in improving people's environmental attitude and concern within the young generation. This is consistent with previous findings that young people were more inclined to embrace emerging concepts or ideas [22] and support environmental protection campaign compared with older generations [6]. For example, McDougle et al. [23] suggest that people tend to be more aware of the Earth within a green landscape. In this way, when faced with an eco-label, the young generation tends to have a higher level of environmental attitude and concern. Our finding tends to further build the logical connection between green consumption and young generation from the perspective of eco-labeling.

In this study, eco-labels showed a significant effect on purchase behavior directly with the path coefficient of 0.199 , which supports H3. Our finding verified the argument of the informative function of eco-label to green consumption [11,12]. As numerous studies doubt the role of eco-label in shaping consumer behavior, our evidence from the young Chinese generation confirms its effectiveness again. For this reason, it is clear that the communication medium of the eco-label, with adequate information, plays a crucial role in green marketing.

Additionally, the eco-label is also a significant predictor of product attributes; the path coefficient of 0.487 supports H4. Limited research has discussed the effect of the eco-label on product attributes, while the current study tries to fill in this research gap by showing that eco-label could have an impact 
on people's perception of product attributes. Prior literature has suggested different types of appeal would have a significant effect in influencing people's purchase intention and advertising attitude towards appeals [51]. However, it does not explore the process of how green appeal influences consumers' perception regarding product attributes. This study tried to extend the previous literature and contribute to the controversy regarding the communicative effect of eco-labels, as it seems to assuage doubts about insufficient indications of eco-labels [1].

Moreover, results show that product attributes enhanced by eco-labels have a significant influence on environmental attitude, with the path coefficient 0.340 supporting H5. However, the environmental concern tends not to be influenced significantly; $\mathrm{H} 6$ is not supported statistically. The reason might lie in the difference between environmental attitude and environmental concern as aforementioned. While environmental attitude might be more associated with individuals' consistent tendencies, perception or evaluation towards the environmental object or related concepts [35], environmental concern might be more related to an actual relief, emotion and commitment towards the environmental issues [77]. Crilly et al. [78] suggested product attributes would be processed at a visual level first and then processed at a behavioral level; it would therefore have a more direct effect on the perceptional level, rather than actual reaction. That might be the reason why product attributes could have a significant effect on environmental attitude while it does not significantly influence environmental concern. A similar observation [6] further suggests that environmental concern is more involved with emotional response and reaction towards an environmental issue while environmental attitude is regarded as a pre-factor influencing cognitive reaction. Furthermore, bootstrap estimation $(n=5000$ resamples) $[79,80]$ confirmed that environmental attitude mediated the effect of product attributes on environmental concern ( $L L C I=0.023, \mathrm{ULCL}=0.140 ; \mathrm{p}=0.005)$, with the effect size of 0.073. We could infer from the present result that, although product attributes play a crucial role in influencing environmental attitude and concern, the impact of product attributes on environmental concern is indirect, mediated by environmental attitude. Our finding tends to inform the present research regarding environmental awareness, that attitudinal awareness plays an indirect role in influencing consumers' purchase behavior.

The influence of environmental attitude on environmental concern is confirmed with a coefficient of 0.186; $\mathrm{H7}$ is supported. It reveals a possible relationship situated in environmental awareness and behavior. Namely, environmental attitude mediated by the factor of environmental concern tends to influence the resulting purchase of environmentally friendly products. This finding tends to inform why ecological knowledge sometimes has little influence on behavioral change [71].

Last, the influence of environmental attitude and environmental concern on green purchase behavior was confirmed with the coefficient of 0.223 and 0.532 respectively, supporting H8 and H9. The results show that environmental attitude and environmental concern are all significant in shaping the young generation's green purchase behavior under the determinant of the eco-label. This is consistent with relevant studies which have suggested the impact of eco-label, environmental attitude, and concern on people's purchase intention $[1,4,64]$.

\section{Conclusions, Implication, and Limitation}

First, the young generation, as a potentially large group for product consumption, has rarely been examined from the eco-label perspective [6]. The current study focused on the role of the eco-label in environmental perceptions and behavioral reaction within the context of young Chinese generation and tried to provide a holistic picture among different variables from three levels: product level, perception level, and behavioral level. According to the Chinese age structure of the population report, nearly one-third of the population of China is comprised of people below 24 years old [81]. Therefore, finding a way to improve young people's environmental attitude and environmental concern is a challenge of considerable significance. Our finding suggests an eco-label design-centered framework could have a positive effect on product attributes and environmental perception, thus influencing the young generation's green purchase behavior. 
Limited research has focused on analyzing the mechanism of how eco-labels influences people's perception and consequent behavior. This study offers several theoretical contributions in the field of eco-label, environmental awareness, and green purchase, helping academics to have a deeper sight on this relationship. First of all, this study statistically verified the impact of eco-label mediated by product attributes on environmental attitude and environmental concern, and how green purchase behavior is influenced through this process significantly. Addressing the ambiguous controversy on environmental attitude and environmental concern [37-39,42,77], this study tried to distinguish these two concepts by clarifying those different reactions and processed levels associated with them. To specify, our findings tend to provide preliminary evidence that environmental attitude and environmental concern should be treated separately and environmental attitude would have a positive effect on environmental concern in the perceptual level. It validates the process and mechanism around how product attributes could influence people's green purchase behavior statistically. By identifying the mediation role of environmental attitude in this process, we could find that product attributes could not directly influence environmental concern. Instead, it could influence environmental concern indirectly through influencing environmental attitude.

Last, limited previous research has examined the relationship between product attributes and the eco-label. Prior research mainly focused on discussing the effect of eco-label and product attributes on green purchase separately $[20,47,48]$. However, as a crucial element of product attributes, the eco-label could influence consumers' perceptions regarding its product category [82]. Rarely studies have analyzed the impact of eco-label in influencing product attributes; the current study tried to fill in this theoretical gap by empirically exploring the role of the eco-label in affecting product attributes towards environmental perception and behavioral reaction. In this study, product attributes were significantly influenced by eco-labeled information, suggesting eco-label design could work as an effective tool to improve the young generation's cognition of product attributes. From the managerial point of view, people would have a more positive attitude towards products with the eco-label design.

From the managerial point of view, this study also provided several practical implications. First of all, the results show that it is an effective way to improve the young generation's environmental attitude and environmental concern by introducing eco-label in the product design process. Since eco-label could significantly increase the young generation's green purchase behavior, commercial companies or institutes, especially those mainly aims at young people, would also have a greater tendency to adopt pro-environmental technologies in their manufacturing process then be licensed to introduce eco-labels in their product design under related regulation, thus improving their sale volume in the end. Future research would try to extend the current framework by introducing other potential related variables, such as consumer affect and PCE.

The current study has some limitation in methodology. Since the participants recruited in this study are mainly in two normal universities from Beijing and Anhui in which the majority gender for both universities is female, as a result, there might exist a gender bias in the current study. However, the majority of the studies concerning gender differences in social behavior are based on social role theory and evolutionary psychology, suggesting that human beings are the given passive role holders; males and females are socialized differently and play different roles in our society [83]. In the context of environmental protection activities, prior research has shown no significant difference between males and females on pro-environmental behavior [84], thus we would predict the influence of gender difference on environmental attitude and environmental concern might be insignificant. Further study would be implemented in a comprehensive university where gender would be balanced to some degree, strengthening the current result. Besides, the young generation, by the Merriam-Webster definition, refers to youth usually between the ages of 12 and 24, and no criteria or requirement on education background is involved in this definition. Although some previous literature also used university students to represent the young generation, analyzing their sustainable behavior [85], it might be inappropriate to sample university students only. Future studies would be conducted 
in a more balanced and accurate sample size. Additionally, the AVE for eco-label is relatively low. Future studies would try to employ different eco-label scales to validate the current findings.

Author Contributions: Conceptualization, methodology and data processing, data curation, writing, formal analysis, Y.S. Research design, data collection, formal analysis, writing-review \& editing, Z.Q. Writing review, Q.Y.

Acknowledgments: We wish to thank Yang Jin who helped to send out the questionnaire, and the students who gave their time to take part in the research.

Conflicts of Interest: The authors declare no conflicts of interest.

\section{Appendix A}

Measurement items of eco-label, environmental awareness, product attributes and green purchase (five-point Likert scale).

Product Attributes (Praxmarer, 2011 and Chen et al. 2015)

- Eco-friendly designed product looks appealing.

- Eco-friendly designed product looks stylish.

- Eco-friendly product is of good quality.

Eco-Label (Nittala, 2014)

- If possible, I would like to buy products with recycling label.

- Marketers must advertise the environmental aspects of their products.

- Government must make eco-labeling mandatory.

Environmental Attitudes (Kim, 2011)

- When humans interfere with nature it often produces disastrous consequences.

- The balance of nature is very delicate and easily upset.

- We are approaching the limit of the number of people the Earth can support.

Environmental Concern (Straughan and Roberts, 1999)

- I try to buy energy-efficient household appliances.

- I try to buy products that can be recycled.

- To save energy, I drive my vehicle as little as possible.

Green Purchase (Kim and Choi. 2005)

- I make a special effort to buy paper and plastic products that are made from recycled materials.

- I have switched products for ecological reasons.

- When I have a choice between two equal products, I purchase the one less harmful to other people and the environment.

- I make a special effort to buy household chemicals such as detergents and cleaning solutions that are environmentally friendly.

- I have avoided buying a product because it had potentially harmful environmental effects.

\section{References}

1. Joshi, Y.; Rahman, Z. Factors affecting green purchase behaviour and future research directions. Int. Strategy. Manag. Rev. 2015, 3, 128-143. [CrossRef]

2. Chen, Y.S.; Chang, C.H. Enhance green purchase intentions: The roles of green perceived value, green perceived risk, and green trust. Manag. Decis. 2012, 50, 502-520. [CrossRef] 
3. Gilg, A.; Barr, S.; Ford, N. Green consumption or sustainable lifestyles? Identifying the sustainable consumer. Futures 2005, 37, 481-504. [CrossRef]

4. Chan, R.Y.K. Environmental attitudes and behavior of consumers in China. J. Int. Consum. Mark. 1999, 11, 25-52. [CrossRef]

5. Martinsons, M.G.; So, S.K.K.; Tin, C.; Wong, D. Hong Kong and China: Emerging markets for environmental products and technologies. Long Range Plan. 1997, 30, 277-290. [CrossRef]

6. Lee, K. Opportunities for green marketing: Young consumers. Mark. Intell. Plan. 2008, 26, 573-586. [CrossRef]

7. Mukhtar, D.; Shen, F.; Shin, L.; Nazli, N.D.M.; Rahim, N.A.A.; Adnan, S.M.; Hassan, H. Influencing factors of purchasing behaviour among generation $\mathrm{Y}$ on green products in universities and colleges. Intercont. J. Mark. Res. Rev. 2017, 5, 20-35.

8. Minkov, N.; Bach, V.; Finkbeiner, M. Characterization of the cradle to cradle certified ${ }^{\mathrm{TM}}$ products program in the context of eco-labels and environmental declarations. Sustainability 2018, 10, 738. [CrossRef]

9. Grankvist, G.; Dahlstrand, U.; Biel, A. The impact of environmental labelling on consumer preference: Negative vs. positive labels. J. Consum. Policy. 2004, 27, 213-230. [CrossRef]

10. Shen, J. Understanding the determinants of consumers' willingness to pay for eco-labeled products: An empirical analysis of the china environmental label. J. Serv. Sci. Manag. 2012, 5, 87-94. [CrossRef]

11. Sammer, K.; Wüstenhagen, R. The influence of eco-labelling on consumer behaviour: Results of a discrete choice analysis for washing machines. Bus. Strategy Environ. 2006, 199, 185-199. [CrossRef]

12. Thøgersen, J. Psychological determinants of paying attention to eco-labels in purchase decisions: Model development and multinational validation. J. Consum. Policy. 2000, 23, 285-313. [CrossRef]

13. Tang, E.; Fryxell, G.E.; Chow, C.S.F. Visual and verbal communication in the design of eco-label for green consumer products. J. Int. Consum. Mark. 2004, 16, 85-105. [CrossRef]

14. Van Amstel, M.; Driessen, P.; Glasbergen, P. Eco-labeling and information asymmetry: A comparison of five eco-labels in the Netherlands. J. Clean. Prod. 2008, 16, 263-276. [CrossRef]

15. Horne, R.E. Limits to labels: The role of eco-labels in the assessment of product sustainability and routes to sustainable consumption. Int. J. Consum. Stud. 2009, 33, 175-182. [CrossRef]

16. Tanner, C.; Kast, S.W. Promoting sustainable consumption: Determinants of green purchases by Swiss consumers. Psychol. Mark. 2003, 20, 883-902. [CrossRef]

17. Gardner, G.T.; Stern, P.C. Environmental Problems and Human Behavior; Allyn \& Bacon: Boston, MA, USA, 1996; ISBN 0205156053.

18. Hill, H.; Lynchehaun, F. Organic milk: Attitudes and consumption patterns. Br. Food J. 2002, 104, $526-542$. [CrossRef]

19. Chen, C. Design for the environment: A quality-based model for green product development. Manag. Sci. 2001, 47, 250-263. [CrossRef]

20. Yau, Y. Eco-labels and willingness-to-pay: A Hong Kong study. Smart Sustain. Built Environ. 2012, 1, $277-290$. [CrossRef]

21. D'Souza, C.; Taghian, M.; Lamb, P.; Peretiatko, R. Green decisions: Demographics and consumer understanding of environmental labels. Int. J. Consum. Stud. 2007, 31, 371-376. [CrossRef]

22. Kanchanapibul, M.; Lacka, E.; Wang, X.; Chan, H.K. An empirical investigation of green purchase behaviour among the young generation. J. Clean. Prod. 2014, 66, 528-536. [CrossRef]

23. McDougle, L.M.; Greenspan, I.; Handy, F. Generation green: Understanding the motivations and mechanisms influencing young adults' environmental volunteering. Int. J. Nonprofit Volunt. Sect. Mark. 2011, 16, 325-341. [CrossRef]

24. Clemenz, G. Eco-Labeling and horizontal product differentiation. Environ. Resour. Econ. 2010, 45, 481-497. [CrossRef]

25. Bougherara, D.; Combris, P. Eco-labelled food products: What are consumers paying for? Eur. Rev. Agric. Econ. 2009, 36, 321-341. [CrossRef]

26. Aceti, J. Recycling: Why People Participate; Why They Don't. A Barrier/Motivation Inventory: The Basis of Community-Based Social Marketing; Department of Environmenttal Protection, Municipal Recycling Branch: Boston, MA, USA, 2002.

27. Giridhar, T. Eco-labelling: A comparative analysis. Chem. Bus. 1998, 12, 95.

28. Gosselt, J.F.; van Rompay, T.; Haske, L. Won't get fooled again: The effects of internal and external csr eco-labeling. J. Bus. Ethics. 2017, 1-12. [CrossRef] 
29. Erskine, C.C.; Collins, L. Eco-labelling: Success or failure? Environmentalist 1997, 17, 125-133. [CrossRef]

30. Karl, H.; Orwat, C. Environmental labelling in Europe: European and national tasks. Eur. Environ. 1999, 9, 212-220. [CrossRef]

31. Nilsson, O.S. Rapport fra "forbrugergruppen" under Erhvervsministeriets mærkningsudvalg. In Mærkning: Mærkningsudvalgets Redegørelse; Nordic Council of Ministers: Norwegian, Swedish, 1999; pp. 152-199.

32. D'Souza, C.; Taghian, M.; Lamb, P.; Peretiatkos, R. Green products and corporate strategy: An empirical investigation. Soc. Bus. Rev. 2006, 1, 144-157. [CrossRef]

33. Taufique, K.; Siwar, C.; Talib, B.; Sarah, F.; Chamhuri, N.; Taufique, K.M.R.; Siwar, C.; Talib, B.; Sarah, F.H.; Chamhuri, N. Synthesis of constructs for modeling consumers' understanding and perception of eco-labels. Sustainabiility 2014, 6, 2176-2200. [CrossRef]

34. Fishbein, M.; Ajzen, I. Belief, Attitude, Intention, and Behavior: An Introduction to Theory and Research; Addison-Wesley Pub. Co: Reading, MA, USA, 1975; ISBN 0201020890.

35. Milfont, T.L.; Duckitt, J. The structure of environmental attitudes: A first- and second-order confirmatory factor analysis. J. Environ. Psychol. 2004, 24, 289-303. [CrossRef]

36. Schultz, P.W. New environmental theories: Empathizing with nature: The effects of perspective taking on concern for environmental issues. J. Soci. Issu. 2000, 56, 391-406. [CrossRef]

37. Hines, J.M.; Hungerford, H.R.; Tomera, A.N. Analysis and synthesis of research on responsible environmental behavior: A meta-analysis. J. Environ. Educ. 1987, 18, 1-8. [CrossRef]

38. Karp, D.G. Values and their effect on pro-environmental behavior. Environ. Behav. 1996, 28, 111-133. [CrossRef]

39. Lee, J.A.; Holden, S.J.S. Understanding the determinants of environmentally conscious behavior. Psychol. Mark. 1999, 16, 373-392. [CrossRef]

40. Vining, J.; Ebreo, A. What makes a recycler? A comparison of recyclers and nonrecyclers. Environ. Behav. 1990, 22, 55-73. [CrossRef]

41. Gill, J.D.; Crosby, L.A.; Taylor, J.R. Ecological concern, attitudes, and social norms in voting behavior. Public Opin. Q. 1986, 50, 537-554. [CrossRef]

42. Oskamp, S.; Harrington, M.J.; Edwards, T.C.; Sherwood, D.L.; Okuda, S.M.; Swanson, D.C. Factors influencing household recycling behavior. Environ. Behav. 1991, 23, 494-519. [CrossRef]

43. Xiao, J.; Siu, K. Ethnicity and acculturation of environmental attitudes and behaviors: A cross-cultural study with Brazilians in Canada. J. Bus. Res. 2018, 82, 300-309. [CrossRef]

44. Bamberg, S. How does environmental concern influence specific environmentally related behaviors? A new answer to an old question. J. Environ. Psychol. 2003, 23, 21-32. [CrossRef]

45. Maloney, M.P.; Ward, M.P. Ecology: Let's hear from the people: An objective scale for the measurement of ecological attitudes and knowledge. Am. Psychol. 1973, 28, 583-586. [CrossRef]

46. Van Liere, K.D.; Dunlap, R.E. The social bases of environmental concern: A review of hypotheses, explanations and empirical evidence. Public Opin. Q. 1980, 44, 181. [CrossRef]

47. Tsakiridou, E.; Boutsouki, C.; Zotos, Y.; Mattas, K. Attitudes and behaviour towards organic products: An exploratory study. Int. J. Retail Distrib. Manag. 2008, 36, 158-175. [CrossRef]

48. Aertsens, J.; Mondelaers, K.; Verbeke, W.; Buysse, J.; van Huylenbroeck, G. The influence of subjective and objective knowledge on attitude, motivations and consumption of organic food. Br. Food J. 2011, 113, 1353-1378. [CrossRef]

49. Young, W.; Hwang, K.; McDonald, S.; Oates, C.J. Sustainable consumption: Green consumer behaviour when purchasing products. Sustain. Dev. 2009, 18, 20-31. [CrossRef]

50. Cerjak, M.; Mesić, Ž.; Kopić, M.; Kovačić, D.; Markovina, J. What motivates consumers to buy organic food: Comparison of croatia, bosnia herzegovina, and slovenia. J. Food Prod. Mark. 2010, 16, 278-292. [CrossRef]

51. Schuhwerk, M.E.; Lefkoff-Hagius, R. Green or Non-Green? Does type of appeal matter when advertising a green product? J. Advert. 1995, 24, 45-54. [CrossRef]

52. Thøgersen, J.; Ölander, F. Human values and the emergence of a sustainable consumption pattern: A panel study. J. Econ. Psychol. 2002, 23, 605-630. [CrossRef]

53. Dangelico, R.M.; Pujari, D. Mainstreaming green product innovation: Why and how companies integrate environmental sustainability. J. Bus. Ethics 2010, 95, 471-486. [CrossRef]

54. Mondelaers, K.; Verbeke, W.; van Huylenbroeck, G. Importance of health and environment as quality traits in the buying decision of organic products. Br. Food J. 2009, 111, 1120-1139. [CrossRef] 
55. Smith, S.; Paladino, A. Eating clean and green? Investigating consumer motivations towards the purchase of organic food. Australas. Mark. J. 2010, 18, 93-104. [CrossRef]

56. Magnusson, M.K.; Arvola, A.; Hursti, U.K.; Åberg, L.; Sjödén, P. Choice of organic foods is related to perceived consequences for human health and to environmentally friendly behaviour. Appetite 2003, 40, 109-117. [CrossRef]

57. Simon, F.L. Marketing green products in the triad. Columbia J. World Bus. 1992, 27, 268-285.

58. Bergstrom, J.C.; Stoll, J.R.; Randall, A. The Impact of information on environmental commodity valuation decisions. Am. J. Agric. Econ. 1990, 72, 614-621. [CrossRef]

59. Cameron, T.A.; Englin, J. Respondent experience and contingent valuation of environmental goods. J. Environ. Econ. Manag. 1997, 33, 296-313. [CrossRef]

60. Teisl, M.F.; Radas, S.; Roe, B. Struggles in optimal labelling: How different consumers react to various labels for genetically modified food. Int. J. Consum. Stud. 2008, 32, 447-456. [CrossRef]

61. Kallgren, C.A.; Wood, W. Access to attitude-relevant information in memory as a determinant of attitude-behavior consistency. J. Exp. Soc. Psychol. 1986, 22, 328-338. [CrossRef]

62. Simmons, D.; Widmar, R. Motivations and barriers to recycling: Toward a strategy for public education. J. Environ. Educ. 1990, 22, 13-18. [CrossRef]

63. Chan, T.S. Concerns for environmental issues and consumer purchase preferences: A Two-Country Study. J. Int. Consum. Mark. 1996, 9, 43-55. [CrossRef]

64. Donaton, S.; Fitch, K. Polls show ecological concern is strong. Advert. Age 1992, 63, 49.

65. Mainieri, T.; Barnett, E.G.; Valdero, T.R.; Unipan, J.B.; Oskamp, S. Green buying: The influence of environmental concern on consumer behavior. J. Soc. Psychol. 1997, 137, 189-204. [CrossRef]

66. Stern, P.C.; Dietz, T.; Guagnano, G.A. The new ecological paradigm in social-psychological context. Environ. Behav. 1995, 27, 723-743. [CrossRef]

67. Schultz, P.W.; Zelezny, L.C. Values and proenvironmental behavior. J. Cross. Cult. Psychol. 1998, 29, 540-558. [CrossRef]

68. Follows, S.B.; Jobber, D. Environmentally responsible purchase behaviour: A test of a consumer model. Eur. J. Mark. 2000, 34, 723-746. [CrossRef]

69. Park, C.W.; Mothersbaugh, D.L.; Feick, L. Consumer knowledge assessment. J. Consum. Res. 1994, 21, 71-82. [CrossRef]

70. Alba, J.W.; Hutchinson, J.W. Knowledge calibration: What consumers know and what they think they know. J. Consum. Res. 2000, 27, 123-156. [CrossRef]

71. Geller, E.S. Evaluating energy conservation programs: Is verbal report enough? J. Consum. Res. 1981, 8, 331-335. [CrossRef]

72. Wu, Z.; Zhang, J.; Detels, R.; Li, V.C.; Cheng, H.; Duan, S.; Li, Z.; Dong, L.; Huang, S.; Jia, M.; Bi, X. Characteristics of risk-taking behaviors, HIV and AIDS knowledge, and risk perception among young males in southwest China. AIDS Educ. Prev. 1997, 9, 147-160. [PubMed]

73. Jiang, J.; Urban, R.; Wang, H.; Bert, K.; Lian, G.; Huang, J.; Greiner, T. Relationship of parental characteristics and feeding practices to overweight in infants and young children in Beijing, China. Public Health Nutr. 2009, 12, 1-6. [CrossRef]

74. Mugge, R.; Schoormans, J.P.L. Product design and apparent usability. The influence of novelty in product appearance. Appl. Ergon. 2012, 43, 1081-1088. [CrossRef] [PubMed]

75. Fornell, C.; Larcker, D.F. Structural equation models with unobservable variables and measurement error: Algebra and statistics. J. Mark. Res. 1981, 18, 382-388. [CrossRef]

76. Huang, C.; Wang, Y.; Wu, T.; Wang, P. An empirical analysis of the antecedents and performance consequences of using the moodle platform. Int. J. Inf. Educ. Technol. 2013, 3, 217-221. [CrossRef]

77. Aman, A.L.; Harun, A.; Hussein, Z. The influence of environmental knowledge and concern on green purchase intention the role of attitude as a mediating variable. Br. J. Arts Soc. Sci. 2012, 7, 145-167.

78. Crilly, N.; Moultrie, J.; Clarkson, P.J. Seeing things: Consumer response to the visual domain in product design. Des. Stud. 2004, 25, 547-577. [CrossRef]

79. Hayes, A.F. An index and test of linear moderated mediation. Multivar. Behav. Res. 2015, 50, 1-22. [CrossRef] [PubMed]

80. Preacher, K.J.; Hayes, A.F. SPSS and SAS procedures for estimating indirect effects in simple mediation models. Behav. Res. Methods Instrum. Comput. 2004, 36, 717-731. [CrossRef] 
81. National Bureau of Statistics. Available online: http:/ / www.stats.gov.cn/tjsj/pcsj/ (accessed on 28 January 2019).

82. Balabanis, G.; Diamantopoulos, A. Domestic country bias, country-of-origin effects, and consumer ethnocentrism: A multidimensional unfolding approach. J. Acad. Mark. Sci. 2004, 32, 80-95. [CrossRef]

83. Pfau-Effinger, B. Gender cultures and the gender arrangement-A theoretical framework for cross-national gender research. Innov. Eur. J. Soc. Sci. Res. 1998, 11, 147-166. [CrossRef]

84. Blocker, T.J.; Eckberg, D.L. Gender and environmentalism: Results from the 1993 general social survey. Soc. Sci. Q. 1997, 78, 841-858.

85. Hill, J.; Lee, H. Young generation Y consumers' perceptions of sustainability in the apparel industry. J. Fash. Mark. Manag. Int. J. 2012, 16, 477-491. [CrossRef]

(C) 2019 by the authors. Licensee MDPI, Basel, Switzerland. This article is an open access article distributed under the terms and conditions of the Creative Commons Attribution (CC BY) license (http://creativecommons.org/licenses/by/4.0/). 